\title{
The challenges of managing degree apprentices in the workplace
}

A manager's perspective

\author{
Lisa Rowe and Daniel Moss \\ Centre for Work Related Studies, Faculty of Business and Management, \\ University of Chester, Chester, UK \\ Neil Moore \\ International Thriving at Work Research Group, \\ University of Chester, Chester, UK, and \\ David Perrin
Centre for Work Related Studies, Faculty of Business and Management, University of Chester, Chester, UK

\begin{abstract}
Purpose - The purpose of this paper is to explore the issues and challenges facing employers as they manage degree apprentices in the workplace. It examines the relationship between managers and apprentices undertaking a work-based degree. This research is of particular relevance at this time because of the UK Government's initiative to expand the number of apprenticeships in the workplace to three million new starts by 2020, inevitably bringing a range of pressures to bear on employers (BIS, 2015). The purpose is to share early experiences of employer management of degree apprenticeships, and provide a range of recommendations to develop and improve employer and higher education institution (HEI) practice.

Design/methodology/approach - This paper combines desk research with qualitative data drawn from interviews with a range of cross-sector organisations to investigate the employer's experience of developing the new degree apprenticeships. Data are explored inductively using thematic analysis in order to surface dominant patterns and considers the implications of findings upon current and emerging HEI and employer practice and research.

Findings - There were a number of key themes which emerged from the data collected. These included the need for effective, employer-led recruitment processes, careful management of expectations, sound HEI retention strategies, employer involvement and board-level motivators to ensure organisational benefits are derived from effectively situated workplace learning and a focus upon effective, empowering mentoring and support strategies.

Research limitations/implications - As degree apprenticeship standards and programmes are currently at the early stages of implementation, and opportunities, funding and resourcing are rapidly changing in the context of government policy, so too will employer appetite and strategies for supporting degree apprentices, along with apprentice behaviour. This means that additional findings, beyond those highlighted within this paper, may emerge in the near future.

Practical implications - There are a number of practical implications supporting managerial development and support of degree apprentices in the workplace from this research. These are reflected in the findings, and include the development of flexible and collaborative processes, resources, mentor training and networks.

Originality/value - This paper is one of the first published accounts of the employers' perspective of managing a degree apprenticeship within the new policy context in the UK. As a result, the work offers a
\end{abstract}

(C) Lisa Rowe, Daniel Moss, Neil Moore and David Perrin. Published in Journal of Work-Applied Management. Published by Emerald Publishing Limited. This article is published under the Creative Commons Attribution (CC BY 4.0) licence. Anyone may reproduce, distribute, translate and create derivative works of this article (for both commercial \& non-commercial purposes), subject to full attribution to the original publication and authors. The full terms of this licence may be seen at http:// creativecommons.org/licences/by/4.0/legalcode
Managing degree apprentices in the workplace

Received 29 July 2017 Revised 11 September 2017 19 September 2017 Accepted 19 September 2017 
JWAM

9,2

unique insight into the emerging challenges and issues encountered by managers working with degree apprentices in the twenty-first century business environment.

Keywords Management, Work-based learning, Millennials, Mentoring,

Chartered Manager Degree Apprenticeship, Apprentice performance

Paper type Research paper

\section{Introduction}

The introduction of degree apprenticeships is one of the biggest transformations in higher education for decades, hailed as "the greatest opportunity ever seen for anyone concerned with skills and employment" delivering a viable option to develop relevant talent through an attractive paid alternative to customary university programmes (Jeffrey, 2016; City and Guilds Group Industry Skills Board, 2015). By June 2017, less than 150 apprentices nationally were enroled onto the Chartered Manager Degree Apprenticeship (CMDA), a critical growth area for many business schools. Whilst vocational apprenticeships have historically been delivered in many countries, non-technical routes have not previously attained degree level. Predictions suggest a rapid acceleration of degree apprenticeships increasing by 650 per cent in 2017/2018. CMDA enrolments are expected to exceed 3,000.

A desire to deepen the development of higher education institutions (HEIs) to meet the needs of employers and the wider UK economy is powering this reform (Lee, 2012; Wall and Jarvis, 2015). Despite soaring numbers of graduates, employer concerns about the perceived quality of graduates leaving university are intensifying. Increasing complaints of poor graduate work readiness and transferable skills are problematic (Yorke, 2006; Archer and Davison, 2008; Hughes et al., 2013; Chartered Association of Business Schools, 2014). Degree apprenticeships may serve to solve employability and professional issues through their collaborative design and delivery model in partnership with employers and professional bodies. An employer levy applies to large organisations with payrolls exceeding $£ 3$ million, whilst non-levied organisations can claim 90 to 100per cent of the degree cost (BIS, 2016). Concerns have already been raised that internal training policies may merely transfer to apprenticeships, thus maximising the recovery of levy payments (Confederation of British Industries, 2016).

The opportunities presented by developing tacit professional knowledge and critical employability skills through genuine business environments are extensively documented (e.g. Ng and Feldman, 2009; Archer and Davison, 2008; Hughes et al., 2013; Billett, 2014). The fundamental concept is that HEIs working closely with employers and professional bodies to deliver degree apprenticeships promise to directly tackle these issues around employability and professional competence. However, whilst the introduction of degree apprenticeships presents HEIs and employers with an entirely unique opportunity to collaboratively design work-based degrees and embed employability strategies, there are clearly significant challenges for employers to deliver additional support and guidance to apprentices. The implicit expectation is that managers will need to develop and adopt new approaches in order to support and manage colleagues as they progress through degree programmes, combining higher level work-related study with full-time employment.

A rapid acceleration of degree apprentices is predicted with growth predicted to increase by 650 per cent in 2017/2018 taking the CMDA projections to 3,000. As this is a new UK development, there are extremely limited data available, largely driven by government and industry. Societies, governments, employers and institutions have shaped varying international apprenticeship development. Whereas vocational programmes in Germany, Switzerland, Australia and New Zealand are commonplace, apprenticeships in Sweden and Denmark are largely reliant upon student placements and non-technical apprenticeships have not previously attained degree status in the UK (Anderson et al., 2012; Billett, 2016). Furthermore, employability research largely focusses upon mid-careers skill development 
which leaves emergent professional journeys unexplored (Trede et al., 2012; Jackson, 2016). There are however claims that employers are unused to supporting graduates with just 28 per cent receiving any training at all, subsequently affecting their retention, engagement and performance (Accenture Strategy, 2015).

This paper therefore provides a new and unique insight by exploring the challenges faced by employers in managing apprentices through one of the earliest CMDA programmes. In doing so, this paper informs a potential gap in the literature concerning workplace management of degree apprentices, and generates significant impact by identifying the subsequent effects upon performance, engagement and retention.

\section{Challenges of managing degree apprenticeships in the workplace - literature review}

In order to investigate the emerging challenges of managing degree apprentices, the literature review explores the key areas of skill development, the employer-driven pedagogic approach and the mentoring role of managers.

\section{Skill development}

It has already been claimed that educators do not provide learning that is relevant or efficient in developing transferable skills for the workplace (Hager, 1998; Tynjala, 2008; Virtanen et al., 2012). Although academic work exploring work-based learning approaches and partnerships between employers and HEIs offer a range of valuable insights and perspectives (Major, 2005; Garnett, 2007; Major et al., 2011), it is important to recognise that contemporary degree apprenticeship programmes have a range of additional challenges. New degree apprentices are entering a continually changing workplace, classed as the fourth industrial revolution where jobs can quickly evolve or dissipate and mobility is vital. Workforce development often previously focussed upon short-term technical skills, limited by narrowly focussed and outdated curricula (Anderson et al., 2012; Pegg et al., 2012; Kossek and Perrigino, 2016; Schwab, 2017). Inevitably employers are frustrated with escalating costs resulting from poor performance, dwindling retention and engagement, whilst graduates blame employers for insufficient training and opportunities, often exacerbated by weak management (Butler and Felts, 2006; Association of Graduate Recruiters, 2015).

Employers are less interested in technically trained graduates, preferring to recruit employees who can reflect, analyse, critique and synthesise experiences, developing themselves accordingly (Harvey, 2003). The emphasis is upon empowering learners to demonstrate a range of qualities, particularly the ability to think and work "outside the box" through the promotion of lifelong learning and development of conceptual, helicopter and analytical thinking skills (Wisher, 1994, p. 37; Beardwell and Claydon, 2007). With self-development of skills at the forefront of current HRM thinking, HEIs are having to adapt from the deep-rooted continuum of "process based" teaching towards experiential and reflective learning, hallmarks of work-based learning designed in collaboration with employers (Kolb, 1984; Raelin, 1997; Boud and Solomon, 2001; Smith and Paton, 2014). With Western economic performance linked to knowledge stock and human capital, work-based learning interventions have become more prolific, albeit usually limited to consultancy, internships and projects focussed upon critical thinking and problem solving (Foray and Lundvall, 1996; World Economic Forum, 2009).

\section{Employer-driven pedagogic approach}

The introduction of degree apprenticeships gives employers an exclusive chance to influence programmes, ensuring the inclusion of relevant skills enhancing pedagogic 
JWAM

9,2

188

strategies and measurement of their efficacy. Experienced and committed employers have already identified their desired skills for aspiring managers and leaders, informing the design of the CMDA Standard (Chartered Management Institute (CMI), 2015; Institute for Employment Studies, 2015, p. 6). The Standard focusses keenly upon performance with notable reference to underpinning psychological conditions, crucial to identifying the various concepts linking knowledge, skills and behaviours. As a result, a more holistic concept of employer requirements emerges, which can be embedded into the curriculum to cultivate employability (Jackson and Hancock, 2010), ensuring that both practical and theoretical competencies are tested. This provides opportunities for HEIs to explore and develop reciprocal work-related curricula and pedagogies that enable learners to develop advanced cognitive skills, such as critical reflection and problem solving (Rosenshine and Meister, 1994; Gregory, 2016). Similarly, by working closely with employers, academics will have the opportunity to experiment with "relevating" pedagogies that challenge established practitioner mindsets and offer counterintuitive perspectives and approaches (Paton et al., 2014). But whilst HEIs are proficient in producing graduates via more didactic pedagogies, they are limited in their ability to develop such broad workplace skill-driven curricula without appropriate employer support (Yorke, 2006). Increasingly, it is acknowledged that the responsibility for sustaining highly skilled workforces requires continued input from all stakeholders, placing a far greater onus upon employers than the arguably easier HEI driven didactic delivery and technical capability assessment ( $\mathrm{g}$ and Feldman, 2009; Billett, 2014). However, early employer engagement is intermittent, compounded by concerns about commitment, costs and resource implications.

Inevitably, there are inherent risks for HEIs in adopting employer-led, individually negotiated curricula. As with employers, many have not yet engaged, recognising the risks associated with pedagogic inconsistencies resulting in "academy-aligned" programmes as opposed to "academy based" (Dalrymple et al., 2014, p. 78). Clearly, the context in which skills will be established and to some extent verified - through external end point assessment - is largely beyond the HEI's control (United Kingdom Commission for Employment and Skills, 2016). Intangible cultures and norms, organisational type, size, sector and international location can all affect learner opportunities to put theory into practice in the workplace (Billett, 2014). With workplace commitment the priority, apprentices will have less regular opportunities than undergraduates to access university networks, student and academic support teams, peer and social networks which can holistically inform skill development (Rice et al., 2006; Dickinson and Dickinson, 2015). Recent employer-led programmes have attracted complaints about a lack of diverse crosspollinated ideas and underexposure to intercultural interaction with other students (Bishop and Hordern, 2017).

\section{Mentoring role}

Degree apprenticeships have raised a further complexity for HEIs in their implicit requirement to identify and assign an employer mentor to ensure appropriate apprentice support in the workplace. Mentoring relationships can invoke an "exchange of wisdom, support, learning or guidance for the purpose of career growth", supporting the achievement of organisational strategic goals through effective talent management (Parsloe and Wray, 2000, p. 12; Chartered Institute of Personnel and Development (CIPD), 2012). Formally supported, employer-led mentoring has also been found to critically enhance the development of professional skills in the workplace (Metso and Kianto, 2014). Committed role model mentoring is also believed to improve resilience, engagement and performance (Grant et al., 2009; Kao et al., 2014). But the role of mentoring cannot be constrained to senior HR staff concerned with talent management. Many mentors are first-level managers, sometimes contested as inappropriate (Ensher and Murphy, 2011; CIPD, 2012). Regardless 
of status, apprentices must have access to supportive enablers, a role which line managers are arguably better placed to fulfil in providing an opportunity to participate in different tasks and contribute towards and influence outcomes, thus seamlessly integrating curricula and workplace (Rajan-Rankin, 2013). Worryingly though, a recent survey suggests that 49 per cent of employees felt that they were not confident that they could mentor an apprentice with 97 per cent advocating training (Curtis, 2017).

The CMDA effectively compresses qualifications through a work-based learning framework, but this itself may unintentionally create further pressure for apprentices to simultaneously perform as aspiring leaders in a "high prestige occupation", requiring particularly effective employer guidance and support (Kossek and Perrigino, 2016, p. 780). As such, these apprentices will be far more reliant than their graduate predecessors were upon high-quality workplace support crucial to their development. Personal academic tutors and other line managers may also interchangeably assume apprentice-mentoring roles whilst in smaller or less hierarchical structures, a variety of workplace staff may formally or informally mentor, remotely or in person, adding value through burgeoning relationships, which may take many guises (Jack and Donnellan, 2010). A divergence of the timing of efficacy measurement and disagreement over the definition of mentoring has led to low generalisability within the literature with insufficient attention given to status, generational perspectives and timing leading to bias (Ensher and Murphy, 2011; Kao et al., 2014).

Another issue is the extent to which public and private sector organisations alike have often been perceived by the HE sector and its quality systems as being insufficiently focussed on fostering learning and where nurturing learning and development of employees is patchy rather than systematic, with limited support structures in place (Reeve and Gallacher, 2005). Systematic attempts were made to address this previously in the UK through the development of explicitly work-based foundation degrees (Lucas et al., 2007) and through other HEI initiatives (e.g. Critten, 2009), and these approaches have led some to argue that WBL programmes themselves can sometimes be instrumental in fostering the internal structures and relationships within businesses that can potentially help turn them into "learning organisations" (Ions and Minton, 2012). However, others have argued that employer interest in work-based learning is often functionalist and their responsiveness to learning needs most often a product of the adaptability of their organisation more generally (Talbot, 2011). These perspectives remain to be tested in a rigorous way, and degree apprenticeships may offer a way to do this systematically.

Some reports suggest that graduates are taking a more commercial attitude to employment with raised expectations beyond previous generations (Bedingfield, 2005) but recent reports suggesting that only 28 per cent of graduates receive any training at all, subsequently affecting retention, engagement and performance (Accenture Strategy, 2015). Only a third of companies provide compulsory management training and less than half offer it at all leading to blame directed towards individual behaviour rather than organisational policy (ILM, 2011; Association of Graduate Recruiters, 2015). Graduate concern with support and development opportunities is at the forefront of early career dissatisfaction requiring talent management strategies that extend beyond graduate salaries (Robson and Rubin, 2009). The UK continues to suffer with 2.4 million untrained managers, leading to four in five currently classed as "accidental managers" (Chartered Management Institute (CMI), 2017). Recent data suggest that nearly a third of apprentices fail to complete their programmes with 57 per cent of apprentices citing insufficient employer support (Curtis, 2017).

Ironically, degree apprentices should receive more relevant and current high-level management training than their superiors upon whom their development relies. This coupled with a potential generational disconnect may not bode well for future mentoring relationships. 
JWAM

9,2

\section{Methodology}

Because of the comparatively recent introduction of degree apprenticeships in the UK, there has been relatively little time or opportunity for researchers to conduct any meaningful study into their impact and success. Moreover, as highlighted earlier with the more, well-established technical apprenticeship, researchers have tended to focus on their impact on skill development (e.g. Rice et al., 2006) and pedagogical issues rather than on employer experiences. Consequently, it was logical that a qualitative, essentially inductive approach was adopted for this early exploratory study, which has focussed on gathering insights into early "employer-adopters" experiences of the CMDA. Because of the focus on a relatively small number of organisations based within the researchers' catchment area, it was felt that a qualitative approach would enable the gathering of richer insights into both the functional and social interactions that may occur in different organisational settings (Bryman, 1984; Morse, 1994) and the dynamic interpersonal processes that may bear on both the apprentices' and employers' perceptions of their respective experiences.

\section{Data collection}

Semi-structured in-depth interviews were chosen as the most appropriate method of data collection because they provided the degree of flexibility necessary to uncover the various facets of the individual actors' roles and interaction with the programme, enabling the researchers to probe more deeply into each interviewee's feelings and beliefs and tease out the various factors affecting their experiences (Kinnear and Taylor, 1991). Given the exploratory nature of the research, the study chose to favour balance and variety over sample size. A greater emphasis was thus placed on the epistemological opportunity presented in a relatively small number of accessible cases (Stake, 1998). Indeed, cases were selected from amongst the first wave of organisations that had engaged with the new programme and represented both private and public sector employers based in the North West of England. In some cases, multiple participants who had, in various capacities, been engaged with the recruitment, induction and monitoring of the apprenticeship scheme within their organisation were interviewed in order to gain a variety of perspectives. Interview data were collected from four employer organisations spanning aerospace, higher education, electrical engineering and textile manufacturing. All interviews were conducted by telephone and the interviews were taped and transcribed for analysis with the interviewees' permission.

The interview protocol was constructed around a small number of core areas of questioning, namely, each organisation's experience of the programme to date; what the main challenges have been in working with the degree apprentices and what key lessons and advice would the interviewees offer to other organisations considering taking on a degree apprentice. Interviewees were also encouraged to raise any other issues that had arisen as a result of their experiences.

Four employers responded to the request to participate in this research comprising a total population sample in this pilot year, and together hosting eight apprentices on programme since September 2017. A profile of the sample confirms a range of apprenticeship management experience (Table I). Six of the eight apprentices are new employees but only one organisation required recruitment advertising and interview support. In all instances, recruitment decisions were made solely by the host organisation.

\section{Data analysis}

As the study involved a cross-case analysis of different professional roles and perceptions of the CMDA within their organisations, the researchers elected to adopt an essentially variable-oriented approach (Miles et al., 2013), inductively coding the data to help identify any recurring themes and patterns (Eisenhardt, 1989). The interview data from each 
organisation (case) were also examined carefully to determine whether the patterns that emerged in one case were replicated in others (e.g. Yin, 2013). In this way, researchers were able to cycle back and forth through individual cases as well as examine themes across cases, which allowed a richer understanding of the perceptions and experiences of the participating employers across the sample as a whole. By adopting a systematic and objective analysis of the case transcripts, we sought to uncover key themes and any commonality among cases. This approach enabled the identification of core constructs and helped to clarify any relationships among them.

\section{Limitations}

Because of the exploratory small-scale nature of this study, it was not intended to provide a detailed analysis of all employer involvement and perceptions of degree apprenticeship programmes. Moreover, because these programmes have only recently been introduced, employer experiences and evaluations are still emerging and will inevitably change over time. Rather, this study presents a range of anecdotal evidence that reveals some useful insights into the pattern of employer experiences and initial perceptions gained through their own individual experiences. Care was taken concerning the danger of attempting to reconcile the uniqueness of an individual case's experiences with the need to understand any generic processes at work across cases when analysing and interpreting the data gathered (Silverstein, 1988). Finally, the research team were conscious of the potential dangers of possible bias associated with the data collection method (e.g. Miles et al., 2013; Nisbett and Ross, 1980), all of which could lead to spurious interpretation of the findings. Here, measures were taken to cross-check analysis and sense-making interpretation of the interview data amongst the research team.

\section{Findings}

\section{Recruitment}

An important emerging issue with regard the management of degree apprentices was the need to recruit appropriate candidates. Employer data have been extremely positive, particularly where a new recruit has joined the organisation as an apprentice. A resounding theme was the need for effective recruitment strategies, and this is clearly of critical importance. As one MD said: "recruiting the right person is definitely a key aspect to this whole programme", echoed by a HR Manager: "I do think it's all down to recruiting the right candidate initially" (Organisations C and D). One employer experienced in the deployment of highly sophisticated recruitment cycles confirmed their rationale for intensive recruitment activity of apprentices in preference to graduates: "We're able to bring in fresh talent for the business; the future lifeblood of the company. You're getting a lot more time to weigh up the person before you buy them in effect" (A). No distinction was made between employee statuses in any induction processes.

\begin{tabular}{|c|c|c|c|c|c|c|}
\hline Organisation & Levy & Number & Gender & Age & Status & Mentor characteristics \\
\hline A & $\begin{array}{l}\text { Yes } \\
6,000 \text { employees }\end{array}$ & 5 & $\begin{array}{l}4 \text { females, } \\
1 \text { male }\end{array}$ & $18-19$ & $\begin{array}{l}\text { New } \\
\text { employees }\end{array}$ & $\begin{array}{l}\text { Experienced } \\
\text { apprenticeship team and } \\
\text { unit managers }\end{array}$ \\
\hline B & $\begin{array}{l}\text { Yes } \\
1,600 \text { employees }\end{array}$ & 1 & 1 female & 47 & $\begin{array}{l}\text { Existing } \\
\text { employee }\end{array}$ & Experienced HR manager \\
\hline $\mathrm{C}$ & $\begin{array}{l}\text { No } \\
100 \text { employees }\end{array}$ & 1 & 1 female & 21 & $\begin{array}{l}\text { Previous } \\
\text { apprenticeship }\end{array}$ & $\begin{array}{l}\text { Experienced HR manager } \\
\text { and MD }\end{array}$ \\
\hline $\mathrm{D}$ & $\begin{array}{l}\text { No } \\
5 \text { employees }\end{array}$ & 1 & 1 female & 18 & New employee & Managing director \\
\hline
\end{tabular}

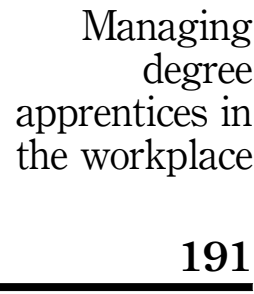


JWAM

9,2

192

\section{Millennials - performance and retention}

Three of the employers had no concerns when questioned about millennials and the possibility of a generational disconnect: "Young people bring a different skillset into what we do. The degree of enthusiasm that I think you get is of course part of being eighteen. It's very, very motivating for the company" (D). However, a slightly different response came from a larger organisation who compared their experience of a mature degree apprentice to a younger, lower level apprentice: "It's just a different focus when you are 18, 19. They were really reluctant to do the work" (B). A further potential issue was also raised with regard to the challenge of managing expectations within multiple cohorts with the comment: "They all want to be managers" (A), although this may result from other contributory factors rather than merely generational. Clearly, assumptions cannot be made concerning any amorphous group who, as individuals, will have different skills and traits. This is particularly evident where rigorous employer-led recruitment methods are deployed, resulting in overwhelmingly positive feedback regardless of age. It is unclear still how well the programme and employers will meet expectations, and whether there is a generational effect upon workplace retention as Bedingfield (2005) suggests.

The CMDA has attracted extremely high-quality applicants and host organisations to date, but retention rates are disappointing compared with traditional undergraduate programmes. Within module one, two apprentices (one mature) had withdrawn from the programme citing workload issues. Subsequently, two further apprentices (one mature) suspended their studies due to health and redundancy. Overall, this represents a disappointing retention rate of 75 per cent within year one. Compressing a degree and fulltime employment into four years is financially advantageous but it is undoubtedly a challenging task. HEIs and employers can draw upon experience of lower level apprentices, which can similarly prove to be problematic, as one respondent said: "Our last apprentice walked away. She didn't even bother completing the apprenticeship” (B). HEIs can support issues of engagement and retention on programme by engendering a sense of belonging through interventions such as regular workplace visits. Although these are resource intense, visits have given staff a valuable opportunity to collaborate with employers in project design and development, as well as surface and resolve issues of management and mentoring at the earliest stage.

The employers' perspective at the degree level was somewhat different, although it must be recognised that an overall retention pattern for degree apprenticeships has yet to be established. Of particular interest was the response from an experienced apprenticeship host: "After 2 years the business can choose which apprentices they want to keep and normally it's not just for their academic ability but it's also the best fit for the business" (A). As a highly sought-after employer with focussed career pathways, they have been able to control recruitment and retention to some extent by deliberately maintaining a balanced intake, benchmarks and deadlines, informing decisions over apprentice retention, rather than the other way around.

\section{Employer-driven pedagogic approach}

Employer-led programme design and ongoing collaboration with providers to effectively situate learning into the workplace can be resource intensive. A particular concern for many businesses is the amount of time apprentices require to spend off the job, but effective provision of genuine work-based learning pedagogy is more efficient for providers, employers and apprentices alike. This has been very successful in generating additional benefits for smaller employers, particularly where MD support is evident: "The projects fit in with things that we actually want to achieve as a business and the benefits are significant. It gives us an opportunity to do things that we wouldn't ordinarily have the time, or the skills to do" (D). Likewise, larger employers have been equally impressed: "The benefits 
outweigh that. She was bringing all this theory into practice. The results have been amazing" (B).

However there was resounding acknowledgement that organisational culture must be one of support, echoing Billett's (2014) warning of its effect upon learning opportunities. One medium-sized SME confirmed this by saying: "One of the biggest things is to have the buy in from the board. Our MD has contributed to the projects that she has done" (C). The most experienced recruiter agreed that the payoff was worth resourcing: "Definitely when you look at the people who've come through and the positions that they're in. $70 \%$ of the senior management team are ex-apprentices who've come through the apprentice programme and that speaks volumes. Some of them are very, very inspiring in the way they speak about the programmes and their experience as well, coming from the apprentice background" (A).

Embedding employability skills into the curriculum is challenging for HEIs, and the apprenticeship standard's design risks this becoming a disjointed, sequential process. However, the work-based learning framework coupled with employer support has achieved the seamless interactive pedagogy proposed by Rajan-Rankin (2013). One example here was the incorporation of 360 degree feedback and smart action planning for skill development. The results from this have been superb: "I can see a change in her already, how she's interacting with other people has changed. And it's just simple things, the way she phrases a question. She's just blossomed in confidence and I think that's been absolutely huge for her" (B). Unsurprisingly, this has also impacted upon other employees as well, benefitting the wider organisation: "What she's bringing back to the team is fantastic as well" (B). Inevitably, some comparisons were made with regard to apprentice vs graduate performance. Whilst only one organisation had extensive experience, they were clear in their endorsement: "Generally an apprentice is someone who is far more grounded and experienced than someone off the direct entry graduate programme" (A).

\section{Mentoring role}

Whilst there have been few issues of note with regard to mentoring and supervision, it is acknowledged that this is a small cohort which has the luxury of intensive HEI support. Interestingly, the role of the mentor was less focussed upon the programme content than expected with the most experienced apprenticeship managers confirming: "So what we do as managers is manage and mentor them through the actual process, rather than the actual skills they need to pass. I don't think that we get down to the actual content of their academic programme" (A). A second employer agreed saying: "It's more supporting them on how they are learning at work as opposed to learning through the academic side of things" (B). However, it is clear that the quality of managerial and supervisory support will be critical to apprentice development in mentoring and guiding project content and delivery, skill development and academic progress. In this study, the role of the mentor was apparent, although it was generally accepted to be a shared responsibility in all but the smallest company (Parsloe and Wray, 2000). In the largest organisation, an apprenticeship manager assumes direct line management, tracking and supporting development through appraisals. Reliance upon departmental managers is a distinct feature of a distributed mentor role, confirmed by the comment: "It's probably a combination actually of the two" (A).

Due to the pilot nature of the programme and small cohort size, the extent to which HEIs will have to rely upon employer mentors remains unexplored to date. A further complication here is that HEIs can only advise employers of the need for a mentor, but they do not have the authority to enforce or monitor this role. Recognising this potential gap in apprentice support, some more experienced HEIs have incorporated academic mentor roles within programme resource structures, whilst others are developing employer-focussed short training programmes, workshops and handbooks, taking Jack and Donnellan's (2010) approach of mentors in many guises. Indeed, this suggestion was welcomed by one 
JWAM

9,2

194

employer who advocated taking more of a coaching approach: "It's not been time consuming, I'm not coaching her through the academic side at all. It's more just like thinking about what the challenges are, giving them that kind of confidence that they are on the right track and that they are coming up with their own objectives, rather than adding more pressure to deadlines, giving them the power to come back" (B).

The data collected have been overwhelmingly positive, despite the inference in the literature that such extensive reliance upon employers and mentors to manage degree apprentice employees may ultimately prove to be problematic. The data gathered have given a rich insight into the employer's experience and will be invaluable in developing strategies as increasing numbers of employers engage with degree apprentices and volume, hierarchy or culture may reduce the availability of appropriate workplace mentors. Despite the small sample size, the findings may be used to continue to develop and improve both employer and HEI practice as the number of apprenticeships in the workplace expands.

\section{Conclusions}

HEIs are developing degree apprenticeship programmes at an unprecedented speed, recognising the lucrative opportunity afforded by an attractive funding proposition combined with rapid growth projections. At the same time, employers are unhappy about graduate employability whilst graduate debt has soared. In adopting an employer-led, work-based delivery model, degree apprenticeships such as the CMDA, HEIs acknowledge the shift in the balance of time afforded to the workplace in lieu of the classroom, and the requirement to embed core employability skills. Here, it is critical that the employer interface is managed effectively so that HEIs can work closely with employers to design curricula and begin to design robust support mechanisms to ensure the effective management and mentoring of apprentices in the workplace.

All of the employers who participated in the first year of the CMDA expressed overwhelming satisfaction with the programme. In particular, their recruitment and selection processes have attracted outstanding candidates who have performed beyond expectations. It appears that genuine support at the board level has made a clear difference to managerial support for apprenticeships, and indeed this is replicated across all types and size of organisation. As a result of this buy-in and the opportunity for businesses to profit from negotiated project content, the mentoring role has proved to be mutually beneficial, as opposed to an onerous drain upon resources. Furthermore, the focus upon talent management processes and learning on the job has remained a distinct employer responsibility as opposed to academic programme, which was seen as the preserve of the provider. This strategy has worked well, whether through an individual or a distributed mentor role, and only one employer was able to make reference to a negative point regarding career expectation management.

However, there are a number of caveats to note, in particular because the programme is a pilot with easily managed numbers. Despite the total population sample, the employers in this study have contributed up to a third of the cost of the degree fees and have committed to doing so over the term of the programme, whereas, in future, funding will be drawn from the levy or will equate to a maximum of 10 per cent. Whilst all host organisations have to pay full-time salaries, the financial commitment from the employers in this study has been substantially more significant than that of future hosts.

The next generation of "novice" apprenticeship providers might have a very different set of requirements. They may be less inclined or able to resource such comprehensive mentoring and support, which, along with large cohort sizes, may subsequently colour the attitudes of apprentices going forward. Both apprentices and graduates are amorphous groups but they may develop positive and negative commonalities, which will become more evident in time. One particular concern may be their retention with disappointing early indications, but as yet unmeasured over the entire four-year programme. 
The research presented here reveals an early insight into the issues and challenges facing employers as they manage degree apprentices, but more cases and longitudinal research are needed to examine relationships and emerging challenges between managers, HEIs and apprentices across different sectors, industries and disciplines. In particular, more data drawn from an international perspective would better inform and support HEI apprenticeship pedagogic design. This would create an international forum for the sharing of best practice, a relevant and timely development, given the potential for apprenticeship reforms in many countries including the USA and Australia (Billett, 2016; Presidential Managing
degree
apprentices in
the workplace Executive Order, 2017; Parker, 2017).

\section{References}

Accenture Strategy (2015), "Accenture U.K. university graduate employment survey", available at: www.accenture.com/t20150706T235021_w__us-en/_acnmedia/Accenture/Conversion-Assets/ DotCom/Documents/Global/PDF/Dualpub_17/Accenture-UK-University-Grad-Research-2015.pdf (accessed 26 July 2017).

Anderson, A., Bravenboer, D. and Hemsworth, D. (2012), “The role of universities in higher apprenticeship development", Higher Education, Skills and Work-based Learning, Vol. 2 No. 3, pp. 240-255.

Archer, W. and Davison, J. (2008), Graduate Employability, The Council for Industry and Higher Education, London.

Association of Graduate Recruiters (2015), “The AGR Annual Survey 2015”, available at: www.agr.org. uk/surveys (accessed 26 July 2017).

Beardwell, J. and Claydon, T. (Eds) (2007), Human Resource Management: A Contemporary Approach, Pearson Education, Harlow.

Bedingfield, C. (2005), "Transforming the ROI of your graduate scheme", Industrial and Commercial Training, Vol. 37 No. 4, pp. 199-203, available at: http://search.proquest.com/docview/214109122? accountid=14620 (accessed 26 July 2017).

Billett, S. (2014), "Integrating learning experiences across tertiary education and practice settings: a socio-personal account”, Educational Research Review, Vol. 12 No. C, pp. 1-13.

Billett, S. (2016), "Apprenticeship as a mode of learning and model of education", Education and Training, Vol. 58 No. 6, pp. 613-628.

BIS (2015), The Future of Apprenticeships in England. Guidance for Trailblazers - From Standards to Starts, Department for Business, Innovation and Skills, available at: www.gov.uk/government/ uploads/system/uploads/attachment_data/file/487350/BIS-15-632-apprenticeships-guidance-fortrailblazers-december-2015.pdf (accessed 26 July 2017).

BIS (2016), Apprenticeship Levy: How it will Work, Department for Business, Innovation and Skills, London, available at: www.gov.uk/government/publications/apprenticeship-levy- how-it-willwork/apprenticeship-levy-how-it-will-work\#accessing-money-paid-under-the- apprenticeshiplevy (accessed 26 July 2017).

Bishop, D. and Hordern, J. (2017), Degree Apprenticeships: Higher Technical or Technical Higher (Education)?, Institute for Education, Bath Spa University, Bath, available at: www.gatsby.org. uk/uploads/education/reports/pdf/degree-apprenticeships-report.pdf (accessed 26 July 2017).

Boud, D. and Solomon, N. (Eds) (2001), Work-Based Learning: A New Higher Education?, SRHE and Open University, Buckingham.

Bryman, A. (1984), "The debate about quantitative and qualitative research: a question of method or epistemology?", The British Journal of Sociology, Vol. 35 No. 1, pp. 75-92.

Butler, M.R. and Felts, J. (2006), "Tool kit for the staff mentor: strategies for improving retention", The Journal of Continuing Education in Nursing, Vol. 37 No. 5, pp. 210-213.

Chartered Association of Business Schools (2014), "21st century leaders building practice into the curriculum to boost employability", available at: www.associationofbusinessschools.org/sites/ default/files/2 1st_century_leaders_june2014_-_final_report.pdf (accessed 26 July 2017). 
JWAM

9,2

Chartered Institute of Personnel and Development (CIPD) (2012), Learning and Talent Development Survey, CIPD, London.

Chartered Management Institute (CMI) (2015), "Chartered manager degree apprenticeship assessment plan", available at: www.managers.org.uk/ /media/Files/PDF/Chartered_Manager_Degree_ Apprenticeship_Assessment_Plan.pdf (accessed 26 July 2017).

Chartered Management Institute (CMI) (2017), "Leadership for change, CMI's management manifesto", June, available at: www.managers.org.uk/ /media/Files/PDF/CMI-Management-Manifesto.pdf (accessed 26 July 2017).

City and Guilds Group Industry Skills Board (2015), "Making apprenticeships work; the employers' perspective", available at: www.cityandguilds.com/ /media/Documents/Courses-andQuals/Apprenticeships/Making\%20Apprenticeships \%20Work_Full\%20report_web $\% 20$ version \%20pdf.ashx (accessed 26 July 2017).

Confederation of British Industries (2016), "Radical rethink required for apprenticeship levy: business concerned about levy but committed to skills", available at: http://educationandskills.cbi.org.uk/ reports (accessed 26 July 2017).

Critten, P. (2009), "Creating a parallel learning organization: a model for work based organisational learning", in Garnett, J. and Young, D. (Eds), Work Based Learning Futures III, UVAC, Bolton, MA, pp. 130-141.

Curtis, R.D. (2017), "Is poor mentor training to blame for almost a third of apprentices dropping out?", HR News, p. 1, available at: http://hrnews.co.uk/poor-mentor-training-blame-almost-thirdapprentices-dropping/ (accessed 26 July 2017).

Dalrymple, R., Kemp, C. and Smith, P. (2014), "Characterising work-based learning as a triadic learning endeavour", Journal of Further and Higher Education, Vol. 38 No. 1, pp. 75-89.

Dickinson, M.J. and Dickinson, D.A.G. (2015), "Practically perfect in every way: can reframing perfectionism for high-achieving undergraduates impact academic resilience?", Studies in Higher Education, Vol. 40 No. 10, pp. 1889-1903.

Eisenhardt, K.M. (1989), "Building theories from case study research", Academy of Management Review, Vol. 14 No. 4, pp. 532-550.

Ensher, E.A. and Murphy, S.E. (2011), Power Mentoring: How Successful Mentors and Protégés Get the Most Out of their Relationships, John Wiley and Sons, London.

Foray, D. and Lundvall, B. (1996), "The knowledge-based economy: from the economics of knowledge to the learning economy", in Peters, M.A. and Humes, W. (Eds), Policy Futures in Education, Vol. 1, Organisation for Economic Co-operation and Development, Paris, p. 6.

Garnett, J. (2007), "Challenging the structural capital of the university to support work-based learning", in Garnett, J. and Young, D. (Eds), Work-Based Learning Futures, University Vocational Awards Council, Bolton, MA, pp. 21-27.

Grant, A.M., Curtayne, L. and Burton, G. (2009), "Executive coaching enhances goal attainment, resilience and workplace well-being: a randomised controlled study", The Journal of Positive Psychology, Vol. 4 No. 5, pp. 396-407.

Gregory, G.H. (2016), Teacher as Activator of Learning, Corwin Press, Thousand Oaks, CA.

Hager, P. (1998), "Recognition of informal learning: challenges and issues", Journal of Vocational Education and Training, Vol. 50 No. 4, pp. 521-535.

Harvey, L. (2003), “Transitions from higher education to work”, Briefing paper prepared by Lee Harvey, with advice from ESECT and LTSN Generic Centre colleagues, Centre for Research and Evaluation, Sheffield Hallam University, available at: http://bit.ly/oeCgqW (accessed 26 July 2017).

Hughes, T., Sheen, J. and Birkin, G. (2013), "Industry graduate skills needs", summary report for the National Centre for Universities and Business. CFE Research, available at: www.ncub.co.uk/ reports/cfe.html (accessed 26 July 2017).

Institute for Employment Studies (2015), "IES annual review", available at: https://view.publitas.com/ institute-for-employment-studi/ies-annual-review-2015/page/1 (accessed 26 July 2017). 
Institute of Leadership and Management (Firm) (2011), "Great expectations: managing Generation Y", Ashridge Business School, available at: www.i-l-m.com/ /media/LLM\%20Website/Downloads/ Insight/Reports_from_ILM_website/research_rpt_generation_y_july2011\%20pdf.ashx (accessed 26 July 2017).

Ions, K. and Minton, A. (2012), "Can work-based learning programmes help companies to become learning organisations?", Higher Education, Skills and Work-Based Learning, Vol. 2 No. 1, pp. 22-32.

Jack, G. and Donnellan, H. (2010), "Recognising the person within the developing professional: tracking early careers of newly qualified child care social workers in three local authorities in England", Social Work Education, Vol. 29 No. 3, pp. 305-318.

Jackson, D. (2016), "Re-conceptualising graduate employability: the importance of pre-professional identity", Higher Education Research and Development, Vol. 35 No. 5, pp. 925-939.

Jackson, D. and Hancock, P. (2010), "Developing non-technical skills in undergraduate degrees in business and their transfer to the workplace”, Education Research and Perspectives, Vol. 37 No. 1, pp. 52-84.

Jeffrey, C. (2016), Is Your Vision the Same or Similar to Mine - Can You See What I See?, Association of Employers and Learning Providers, Bristol, available at: www.aelp.org.uk/ news/aelp-blog/ details/is-your-vision-the-same-or-similar-to-mine-can-you/ (accessed 26 July 2017).

Kao, K.Y., Rogers, A., Spitzmueller, C., Lin, M.T. and Lin, C.H. (2014), "Who should serve as my mentor? The effects of a mentor's gender and supervisory status on resilience in mentoring relationships", Journal of Vocational Behavior, Vol. 85 No. 2, pp. 191-203.

Kinnear, L.H. and Taylor, J.R. (1991), Marketing Research, 3rd ed., McGraw-Hill, London.

Kolb, D. (1984), Experiential Learning: Experience as the Source of Learning and Development, Prentice Hall, London.

Kossek, E.E. and Perrigino, M.B. (2016), "Resilience: a review using a grounded integrated occupational approach", The Academy of Management Annals, Vol. 10 No. 1, pp. 729-797.

Lee, D. (2012), "Apprenticeships in England: an overview of current issues", Higher Education, Skills and Work-based Learning, Vol. 2 No. 3, pp. 225-239.

Lucas, M., Minton, A. and Perrin, D. (2007), "The RAF foundation degrees: meeting employer need - a consortium approach", in Garnett, J. and Young, D. (Eds), Work Based Learning Futures, UVAC, Bolton, pp. 53-64.

Major, D. (2005), "Learning through work-based learning”, in Hartley, P., Woods, A. and Pill, M. (Eds), Enhancing Teaching in Higher Education: New Approaches for Improving Student Learning, Routledge, London, pp. 16-25.

Major, D., Meakin, D. and Perrin, D. (2011), "Building the capacity of higher education to deliver programmes of work-based learning", Higher Education, Skills and Work-Based Learning, Vol. 1 No. 2, pp. 118-127.

Metso, S. and Kianto, A. (2014), "Vocational students' perspective on professional skills workplace learning", Journal of Workplace Learning, Vol. 26 No. 2, pp. 128-148.

Miles, M.B., Huberman, A.M. and Saldana, J. (2013), Qualitative Data Analysis, Sage, Newbury Park, CA.

Morse, J.M. (1994), "Emerging from the data: the cognitive processes of analysis on qualitative enquiry", in Morse, J.M. (Ed.), Critical Issue in Qualitative Research Methods, Sage, Thousand Oaks, CA, pp. 23-46.

Ng, T.W.H. and Feldman, D. (2009), "How broadly does education contribute to job performance?", Personnel Psychology, Vol. 62 No. 1, pp. 89-134.

Nisbett, R.E. and Ross, L. (1980), Human Interface: Strategies and Shortcomings of Social Judgement, Prentice Hall, Englewood Cliffs, NJ.

Parker, S. (2017), "The UK is rethinking university degrees and Australia should too", The Conversation, August 29, available at: https://theconversation.com/the-uk-is-rethinkinguniversity-degrees-and-australia-should-too-82973 (accessed 9 September 2017).
Managing degree apprentices in the workplace 
JWAM

9,2

Parsloe, E. and Wray, M. (2000), Coaching and Mentoring: Practical Methods to Improve Learning, Kogan Page, London.

Paton, S., Chia, R. and Burt, G. (2014), "Relevance or 'relevate'? How university business schools can add value through reflexively learning from strategic partnerships with business", Management Learning, Vol. 45 No. 3, pp. 267-288.

Pegg, A., Waldock, J., Hendy-Isaac, S. and Lawton, R. (2012), Pedagogy for Employability, Higher Education Academy, York.

Presidential Executive Order (2017), Expanding Apprenticeships in America, The White House, Washington, DC, 15 June, available at: www.whitehouse.gov/the-press-office/2017/06/15/ presidential-executive-order-expanding-apprenticeships-america (accessed 9 September 2017).

Raelin, J. (1997), “A model of work-based learning”, Organisational Science, Vol. 8 No. 6, pp. 563-578.

Rajan-Rankin, S. (2013), "Self-identity, embodiment and the development of emotional resilience", British Journal of Social Work, Vol. 44 No. 8, pp. 1-17.

Reeve, F. and Gallacher, J. (2005), "Employer-university 'partnerships': a key problem for work-based learning programmes?", Journal of Education and Work, Vol. 18 No. 2, pp. 219-233.

Rice, K.G., Leever, B.A., Christopher, J. and Porter, J.D. (2006), "Perfectionism, stress, and social (dis) connection: a short-term study of hopelessness, depression, and academic adjustment among honors students", Journal of Counseling Psychology, Vol. 53 No. 4, pp. 524-534.

Robson, F. and Rubin, C. (2009), "Graduate retention: realistic objective or thing of the past? A qualitative study into the antecedents to turnover of graduates early in their career", available at: www.ufhrd.co.uk/wordpress/wp-content/uploads/2009/07/1-16-practitioner-paper. pdf (accessed 26 July 2017).

Rosenshine, B. and Meister, C. (1994), "Reciprocal teaching: a review of the research", Review of Educational Research, Vol. 64 No. 4, pp. 479-530.

Schwab, K. (2017), The Fourth Industrial Revolution, Penguin, Thousand Oaks, CA and London.

Silverstein, A. (1988), “An Aristotelian resolution of the idiographic versus nomothetic tension", American Psychologist, Vol. 43 No. 6, pp. 425-430.

Smith, A.M. and Paton, R.A. (2014), "Embedding enterprise education: a service based transferable skills framework", The International Journal of Management Education, Vol. 12 No. 3, pp. 550-560.

Stake, R.E. (1998), "Case studies", in Denzin, N.K. and Lincoln, Y.S. (Eds), Strategies of Qualitative Inquiry, Sage, Thousand Oaks, CA, pp. 86-109.

Talbot, J. (2011), "Changing power relations in work based learning: collaborative and contested relations between tutors, learners and employers", in Jackson, S. (Ed.), Innovations in Lifelong Learning: Critical Perspectives on Diversity, Participation and Vocational Learning, Routledge, London, pp. 187-208.

Trede, F., Macklin, R. and Bridges, D. (2012), "Professional identity development: a review of the higher education literature", Studies in Higher Education, Vol. 37 No. 3, pp. 365-384.

Tynjala, P. (2008), "Perspectives into learning at the workplace", Educational Research Review, Vol. 3 No. 2, pp. 130-154.

United Kingdom Commission for Employment and Skills (2016), "Employer Skills Survey 2015: UK results", available at: www.gov.uk/government/publications/ukces-employer-skills-survey-2015uk-report (accessed 26 July 2017).

Virtanen, A., Tynjala, P. and Etelapelto, A. (2012), "Factors promoting vocational students' learning at work: study on student experiences", Journal of Education and Work, Vol. 27 No. 1, pp. 43-70.

Wall, T. and Jarvis, M. (2015), Business Schools as Educational Provocateurs of Productivity via Interrelated Landscapes of Practice, Chartered Association of Business Schools, London, available at: http://charteredabs.org/business-schools-as-educational-provocateurs-ofproductivity-via-interrelated-landscapes-of-practice/ (accessed 26 July 2017). 
Wisher, V. (1994), “Competencies: the precious seeds of growth”, Personnel Management, Vol. 26 No. 7, p. 37.

Managing degree

World Economic Forum (2009), "Educating the next wave of entrepreneurs: unlocking entrepreneurial capabilities to meet the global challenges of the 21st century", 2009 report, World Economic Forum, available at: www.ncge.org.uk/publication/educating_the_next_wave_of_entrepreneurs.pdf (accessed 26 July 2017).

Yin, R.K. (2013), Case Study Research: Design and Method, Sage publications.

Yorke, M. (2006), "Employability in higher education: what it is - what it is not", Learning and Employability Series, Vol. 1, available at: www.heacademy.ac.uk/system/files/id116_ employability_in_higher_education_336.pdf (accessed 26 July 2017).

\section{Further reading}

Nikolou-Walker, G. and Garnet, J. (2004), "Work-based learning: a new imperative: developing reflective practice in professional life", Reflective Practice, Vol. 5 No. 3, pp. 197-312.

Yorke, M. (2010), "Employability: aligning the message, the medium and academic values", Journal of Teaching and Learning for Graduate Employability, Vol. 1 No. 1, pp. 2-12.

\section{Corresponding author}

Lisa Rowe can be contacted at: lisa.rowe@chester.ac.uk

For instructions on how to order reprints of this article, please visit our website: 